\title{
THE SVECOKARELIAN OROGENIC CYCLE AND RELATED METALLOGENESIS IN FINLAND ${ }^{(1}$
}

\author{
Tauno Pitrainen
}

\begin{abstract}
Pirrainen Tauno 1975: The Svecokarelian orogenic cycle and related metallogenesis in Finland. Bull. Geol. Soc. Finland 47. 139-153
\end{abstract}

\begin{abstract}
General features of the Svecokarelian orogenic belt in Finland together with the ore deposits and their environments in the belt are reported. The sedimentary groups, igneous phases and ore deposits are considered functions of the orogeny. Three metallogenetic epochs have been found: the first connected with the pre-flysch sedimentation and the initial igneous activity, the second generated by the subsequent magmatism, and the third effected by the late orogenic plutonism.
\end{abstract}

Tauno Piirainen, Department of Geology University of Oulu, Finland. SF-90100 Oulu 10, Finland.

\section{Introduction}

Systematic investigations of the Finnish bedrock have now continued for over 150 years. The investigations began with ore prospecting which, however, due to a lack of knowledge of the bedrock, was not successful. Nils Nordenskiöld, under whose leadership the work was begun, was conscious of the need and pioneered the commencement of basic geological research in the country.

Then, when work began at the end of the last century, knowledge of the bedrock increased rapidly providing evidence that the uniformitarian concept was also useful in investigations

1) Adapted from a lecture given at the Institute of Precambrian Geology and Geochronology in Leningrad USSR, October 9th, 1974. of the fundamental complex (Sederholm 1891, 1897). Under Sederholm's leadership the general features of the Finnish bedrock were geologically surveyed. Sederholm's classification was based mainly on the relationship of the supracrustal rocks to epochs of diastrophism and to the granites which have been intruded during these epochs. According to him (1932), it was possible to find in the Finnish bedrock three different cycles of sedimentation followed by epochs of diastrophism which he named post-Svionian, post-Bothnian and post-Jatulian respectively. The Svionian and Bothnian sediments were visible in western Finland and the Jatulian in eastern and northern Finland.

Sederholm's opinions formed the basis for later investigations. However, it soon became obvious that the post-Bothnian and post- 
Svionian diastrophisms were the same (Mäkinen 1914). This orogenic belt, which covered the Svionian and Bothnian schist zones was then called Svecofennian. During this orogeny two groups of igneous rocks could be indicated, which were considered synorogenic and late orogenic (Saksela 1932). Investigations in eastern and northern Finland indicated another orogenic belt striking from southeast to north-west. This belt was called Karelian (Eskola 1927; Väyrynen 1928; Wegman 1928).

Knowledge of these belts has now been increased by continuous geological surveying, geophysical measurements, age determinations and other separate investigations. The discordance between the Svecofennian and Karelian belts was, however, never found. In addition to this, age determinations indicated that the granites in both belts were of the same age (Kouvo 1958). Therefore, opinions had again to be changed. According to the new interpretation the Svecofennides and Karelides were generated during the same orogenic cycle (Mikkola 1953; Metzger 1959; Simonen 1960 a 1960 b). The orogenic cycle interpreted in this new way has, in recent years, been called Svecokarelian.

At the beginning of the investigations it seemed that ore deposits were lacking from the Finnish bedrock. This opinion has proved to be wrong. In fact, 11 ore deposits are being mined in Finland at the present time. They produce rawmaterials for our metal industries for the production of copper, zinc, nickel, cobalt, iron, vanadium pentoxide, titanium oxide, ferro chrome gold, silver, sulphur and selenium. In addition to these deposits there are numerous others, which have been worked out or which are not of any economic importance, but are scientifically interesting. The most of the ore deposits lie within the Svecokarelides. The ores and their environments offer very rewarding material for an investigation, of how metallogenesis is dependent upon orogenesis. The subject is very comprehensive, and it contains yet many unreselved problems, on which depending the examination of the dilemma within one lecture can be only general and tentative.

\section{The Svecokarelian orogenic belt}

According to the new interpretation, the Finnish bedrock (Fig. 1) is composed predominantly of two great structural units, the pre-Svecokarelian besement complex and Svecokarelian belt (Simonen 1971). The pre-Svecokarelian basement complex covers large areas in eastern Finland, but disappears to the south-west under the Svecokarelides, where it has been remobilized during the Svecokarelian orogeny. This orogeny generated two different schist zones, which have been called Karelian and Svecofennian.

\section{The Karelian schist zone}

The Karelian schist zone (Fig. 1, Table I) begins in the south-eastern part of the country as the North Karelian schist area. To the northwest the schist zone is cut by the basement complex but it appears again in Kainuu where it forms a separate area, the so-called Kainuu schist area. From Kainuu the Karelian schist zone extends far to the north-west covering large areas around the batholith of Central Lapland.

All the separate schist areas of the Karelian schist zone are, in their essential proportions, similar to each other. In each area the bedrock is composed of the basement complex, Karelian metasediments and basic igneous rocks, while in places (e.g. in Central Lapland) granites are widely exposed.

The basement complex consists mainly of different gneisses. In places gneisses may be replaced by schists, which are ancient graywackes and volcanics. The schists are cut by granites, which are dated to 2.8 billion years (Kouvo 1958; Kouvo et al. 1963; Kouvo \& Tilton 1966).

The discordance between the basement com- 


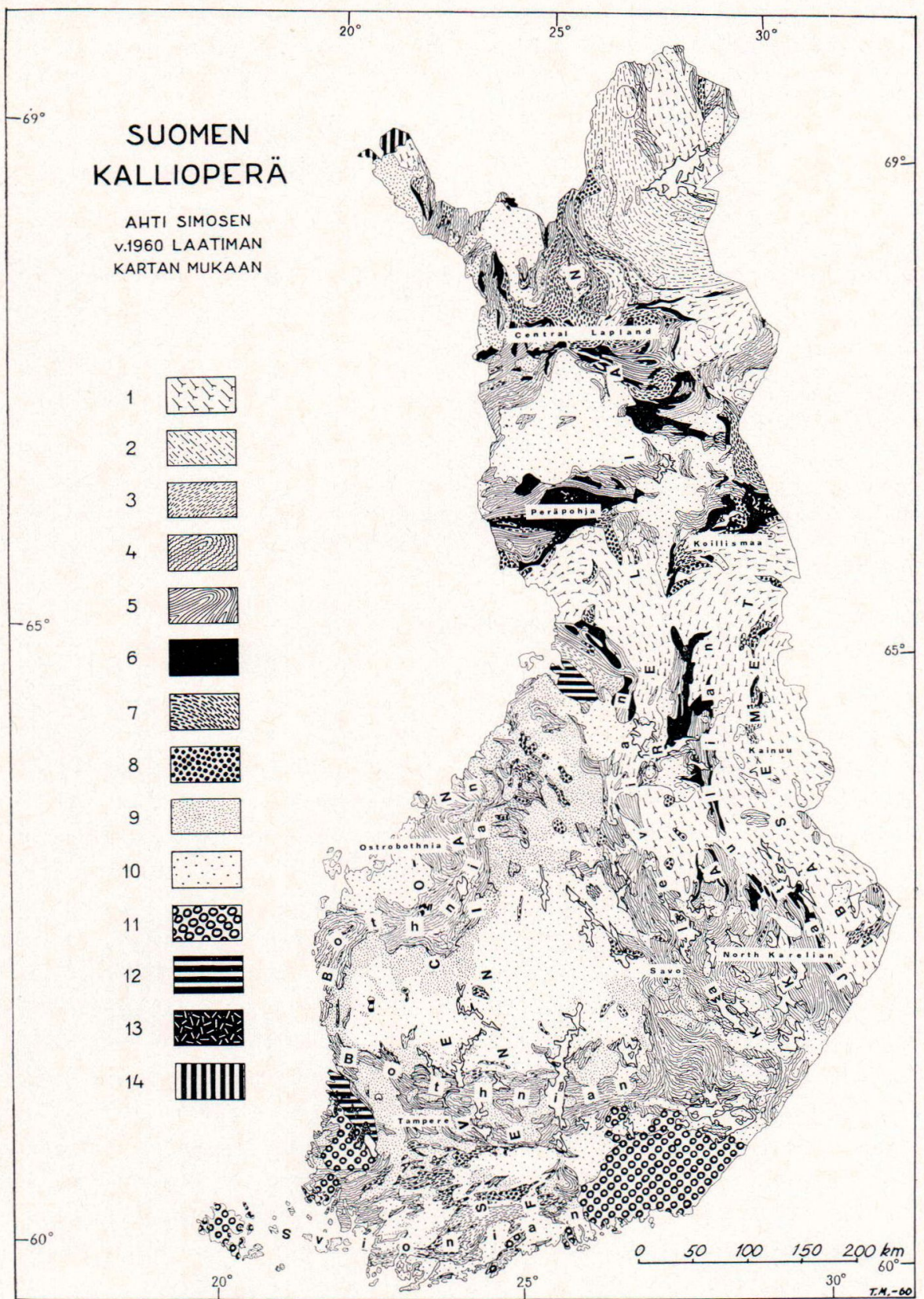

Fig. 1. Geological map of Finland after Simonen 1960

1. granite gneiss

2. granulite

3. leptite

4. mica gneiss and migmatite

5. phyllite and mica schist

6. quartzite

7. metabasalt and amphibolite
8. gabbro, anorthosite and perdotite

9. granodiorite and quartz diorite

10. granite and acid plutonic rocks in general

11. rapakivi and other anorogenic granites

12. unmetamorphosed sedimentary rocks

13. diabase (Jotnian)

14. Paleozoic schist (Caledonian) 
TABLE 1.

Main sedimentary groups and igneous phases in the Karelian schist zone

\begin{tabular}{|c|c|c|}
\hline Sedimentary rocks & Igneous rocks & $\begin{array}{c}\text { Age } \\
\text { in b.y. }\end{array}$ \\
\hline $\begin{array}{l}\text { Conglomerates and arkose quartzites in the } \\
\text { Central Laplan schists area }\end{array}$ & Granites & \multirow[t]{3}{*}{1.8} \\
\hline $\begin{array}{l}\text { Upper Kalevian group: graywacke-slates, phyllites } \\
\text { and conglomerates in the Central Lapland } \\
\text { schists area }\end{array}$ & $\begin{array}{l}\text { Basic and salic igneous rocks in northern } \\
\text { Finland }\end{array}$ & \\
\hline $\begin{array}{l}\text { Kalevian group: conglomerates, quartzites, } \\
\text { phyllites and graywacke-slates }\end{array}$ & Local remobilization and remelting & \\
\hline $\begin{array}{l}\text { Jatulian group: conglomerates, orthoquartzites, } \\
\text { arkose quartzites, dolomites, phyllites, iron } \\
\text { formations and black schists }\end{array}$ & $\begin{array}{l}\text { Tholeiitic and spilitic lavas, sills and dikes; } \\
\text { layered intrusions }\end{array}$ & 2.1 \\
\hline Basem & nplex & 2.8 \\
\hline
\end{tabular}

plex and the Karelian schists is everywhere distinct, except in some areas in Central Lapland and the south-western part of the zone. The Karelian schists are subdivided into sedimentary groups, Jatulian and Kalevian.

The sediments of the Jatulian group are, in general, well sorted and strongly weathered chemically, to which the orthoquartzites, dolomites, black schists and iron formations bear evidence. According to Väyrynen (1954, p. 172) they are evolutionary in respect of their character. The group is further divided into formations (Piiranen 1968; Piiranen et al. 1974; Silvennoinen 1972), which are separated by hiatuses in the marginal regions of the schist areas, but elsewhere the hiatuses may disappear and the formations grade gradually into each other. The different formations cannot be correlated from one schist area to another, which provides evidence for the opinion that the separate schist areas developed in more or less independent sedimentary basins during Jatulian time.

In places the Jatulian formations are separated from each other by basic lavas and elsewhere they are cut by dikes and sills (Piirainen 1968; Piispanen 1971; Silvennoinen 1972). The lavas and hypabyssic intrusions involve tholeiites and spilites. In some spilitic sills a differetiation series is visible from ultrabasic rocks through albite diabases to albites. In addition to the sills and dikes layered intrusions have been found between the basement and the Karelian metasediments (Piirainen \& Hugg et al. 1974). According to age determinations made on the zircon of albite diabases the igneous bodies are 2.1-2.2 billion years old (Sakko 1971).

The Jatulian sedimentary group and the basic igneous rocks are covered by the Kalevian sedimentary group over wide areas. The Kalevian sediments are not as thoroughly sorted as the Jatulian, and Väyrynen (op. cit.) describes them as revolutionary in character in contrast to the Jatulian sediments. The Kalevian sedimentary group is composed of graywacke-slates, which are characterized by graded bedding giving evidence of turbidity currents (Piirainen $e t$ al. 1974). Basic volcanics, which are common in the Jatulian group, have never been found in connec- 
TABLE 2.

Main sedimentary groups and igneous phases in the Svecofennian schist zone

\begin{tabular}{|c|c|c|}
\hline Sedimentary rocks & Igneous tocks & $\begin{array}{c}\text { Age } \\
\text { in b.y. }\end{array}$ \\
\hline & Microcline granites & 1.8 \\
\hline $\begin{array}{l}\text { Upper Bothnian group: graywacke-lates, con- } \\
\text { glomerates and associated beds of other sedi- } \\
\text { mentary rocks }\end{array}$ & $\begin{array}{l}\text { Salic, intermediate and basic volcanies; basic and } \\
\text { ultrabasic pipe-like intrusions; salic intrusions }\end{array}$ & 1.9 \\
\hline Lower Bothnian group: graywacke-lates & Remobilization and remelting & \\
\hline $\begin{array}{l}\text { Svionian group: leptites, amphibolites, } \\
\text { kinzigites, mica schists, limestones, iron } \\
\text { formations and black schists }\end{array}$ & $\begin{array}{l}\text { Highly metaporphosed basic, intermediate and } \\
\text { salic lavas }\end{array}$ & \\
\hline
\end{tabular}

tion with the Kalevian sediments (Väyrynen 1933), which supports the point of view that the geotectonic state of the zone changed after Jatulian time.

The seguence is more complicated in the Central Lapland schist area. The Kalevian sedimentary group is overlain by graywackes, phyllites, quartzites and conglomerates. According to Mäkelä (1968) these sediments can be divided into two groups. The lower group, which is called upper Kalevian in this paper, is cut by basic igneous rocks (Mäkelä, op.cit.).

In many parts of the Karelian schist zone the metamorphic facies has been so low that recrystallization of the sediments has taken place in the albite-epidote-amfibolite- or greenschist facies (Piirainen 1968; Paakkola 1971; Piispanen 1971). The degree of metamorphosis increases, however, to the west and to the center of the sedimentation basin in northern Finland. There, the highly metamorphosed sediments are cut by salic igneous rocks of two generations, dated to 1.8 and 1.9 billion years old (Kouvo 1958; Geol. Surv. Finland 1966-1972).

\section{The Svecofennian zone}

To the south-west of the Karelian schist zone, as mentioned above, the degree of metamorphosis increases. Simultaneous with this increase the Karelian schist zone changes to the Svecofennian schist zone (Fig. 1, Table II) without any plane boundary. Moreover, the discordance between the basement and the younger formations, which was so distinct in the Karelian zone, is no longer recognizable because of major folding and remobilization. Large areas of the zone are dominated by the batholith of Central Finland, around which the Svionian and Bothnian schists are, however, visible.

The Svionian schists are best known in southwestern Finland (Fig. 1), where they form a schist zone running from east to west. This schist zone has been investigated by Eskola (1914), Metzger (1945), Härme (1954), Tuominen (1957) etc. Accotding to them the zone contains leptites, limestones, mica schists, amphibolites, and cordierite-antophyllite rocks. In respect of the large amount of limestone, the related sedi- 
mentary group seems to be, like the Jatulian, evolutionary in character. In many places the schists change to migmatites and gneisses, among which kinzigites play a great role. Furthermore in this zone there are salic intrusives of at least two different generations (Eskola 1914). The granites of the younger generation are determinated by Kouvo (1958) to be 1.8 billion years old.

The Bothnian schists are best known in Tampere area (Fig. 1), where they have been studied by Sederholm (1897), Seitsaari (1951), Simonen (1953) etc. The schists lie within gneisses, which gradually change upwards into graywacke-slates which have been deposited by turbidity currents. The graywacke-slates are overlain by arkoses, conglomerates, and salic, intermediate, and basic volcanics (Simonen 1953). The conglomerates and arkoses contain pebbles from Svecokarelian salic plutonic rocks (Matisto 1968) about 1.9 billion years old (Geol. Surv. Finland 1966). At lower levels basic, ultrabasic, and salic plutonic rocks of about same age as the pebbles, and thus also the volcanics, are common (Geol. Surv. Finland 1968, 1970, 1971 and 1972). The available data from the Bothnian schist zone suggest that the lower and upper parts of the zone were deposited within quite different geotectonic circumstances: the development of the lower part is characterized by the subsidence of the bottom whereas the upper part was deposited during the regression and vigorous igneous activity. Both parts have been recrystallized within the amphibolite facies (Seitsaari 1951) and are cut by granites 1.8 billion years old (Kouvo 1958).

\section{The Svecokarelian ore deposits}

The most favourable milieu for ores in the Svecokarelian belt seems to be the Jatulian and Svionian sediments involving volcanics (Fig. 2, Table III, Ore dep. 1-34). Ore deposits have also been found in the Bothnian volcanics and in the related basic, ultrabasic, and salic intrusives around the batholith of Central Fin- land (Fig. 3, Table III, Ore dep. 35-50). Then there is a third group of deposits which is connected with the granites which, in many places, cut the Finnish bedrock (Fig. 3, Table III, Ore dep. 51-53). The ages of these groups are around 2.1, 1.9 and 1.8 billion years respectively (Geol. Surv. Finland 1965, 1972; Kahma 1973).

The ore deposits connected with the Jatulian and Svionian schists and volcanics vary largely in their composition. With respect to the metal composition the ores can be divided into U-(V)-, $\mathrm{Fe}-$ and $\mathrm{Fe}-(\mathrm{Mn})-$, Cr-, Fe-Ti-V-, Ni-Cu-(Pt)-, $\mathrm{Cu}-(\mathrm{Co})-$ and $\mathrm{Zn}-\mathrm{Cu}$-types.

$\mathrm{U}-(\mathrm{V})$-ores have been found in many places in the Jatulian quartzites, for example in the KoliKaltimo (1) area in North Karelia and Kesänkitunturi (2) in the north-western part of the schist area of Central Lapland. The mineralizations follow the same stratigraphic horizon over extensive areas. In this horizon they have also been found at the contacts with basic sills and dikes (Piirainen 1968).

Iron, with or without manganese, has formed ironformations within the marine environments. They have been found within the Jatulian sediments, particulary in the schist area of Central Lapland, but also within the Svionian schists in south-western Finland and in places in Ostrobothnia. In addition to the ironformations, sulphide ore deposits closely connected with black schists, cherts and carbonate rocks are also found in the pelites. In the Karelian schist zone the deposits are of $\mathrm{Cu}-(\mathrm{Co})$-ores with small amounts of zinc, but in the Svecofennian zone they are composed of zinc and iron sulphides only, with small amounts of copper minerals. The large ore bodies such as Outokumpu (13), Vuonos (14), Luikonlahti (15), and Hammaslahti (16) in North Karelia represent the former type of ore. In addition to these hundreds of dikelets of the same metal composition are known in the spilitic sills and dikes connected with the Jatulian quartzite. The latter type, the $\mathrm{Zn}$-Cu-pyrite-ore, forms the large ore bodies of Vihanti (23) and Pyhäsalmi (24) within the schists of Svionian 


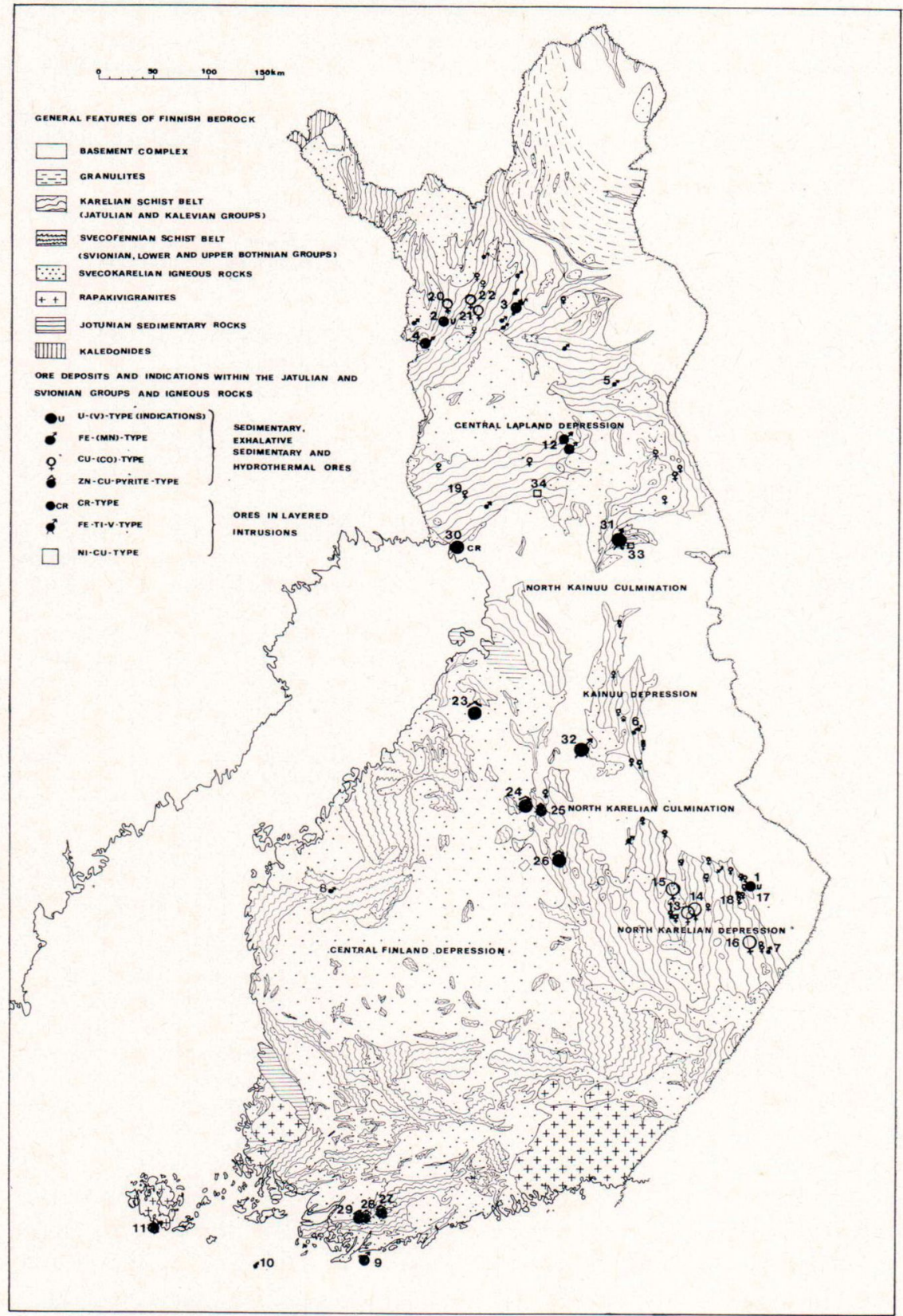

Fig. 2. Ore deposits connected with the Jatulian and Svionian schists and related igneous rocks. 
TABLE 3.

Main ore deposits and their environments in the Svecokarelian orogenic belt.

\begin{tabular}{|c|c|c|c|}
\hline Type & Ore deposits & Environment & $\begin{array}{c}\text { Age } \\
\text { group }\end{array}$ \\
\hline $\mathrm{U}-(\mathrm{V})-$ & Paukkajanvaara (1), Kesänkitunturi (2) & $\begin{array}{l}\text { Jatulian quartzites; tholeiitic and spilitic } \\
\text { sils and dikes }\end{array}$ & \multirow{6}{*}{2.1} \\
\hline $\mathrm{Fe}-(\mathrm{Mn})-$ & $\begin{array}{l}\text { Porkonen-Pahtavaara (3), KOLARI (4), } \\
\text { Jauratsi (5), Tuomivaara (6), Valkea- } \\
\text { vaara (7), Vittinki (8), Jussaari (9), } \\
\text { Kalkskär (10), Nyhamn (11) }\end{array}$ & $\begin{array}{l}\text { Jatulian mica schists, black schists, } \\
\text { carbonates and cherts; spilitic volcanics; } \\
\text { Svionian sediments and volcanics }\end{array}$ & \\
\hline $\mathrm{Fe}-$ & MISI (12) & $\begin{array}{l}\text { Spilitic differentation series within Jatulian } \\
\text { metasediments }\end{array}$ & \\
\hline $\mathrm{Cu}-(\mathrm{Co})-$ & $\begin{array}{l}\text { OUTOKUMPU (13), VUONOS (14), } \\
\text { LUIKONLAHTI (15), HAMMAS- } \\
\text { LAHTI (16), Kyykkä (17), Hokka (18), } \\
\text { Tervola (19), Pahtavuoma (20), Riikon- } \\
\text { koski (21), Sirkka (22) }\end{array}$ & $\begin{array}{l}\text { Jatulian black schists, carbonates and } \\
\text { cherts; serpentinites; spilitic volcanics, } \\
\text { sills and dikes }\end{array}$ & \\
\hline $\mathrm{Zn}$-Cu-pyrite & $\begin{array}{l}\text { VIHANTI (23), PYHÄSALMI (24), Kal- } \\
\text { liokylä (25), Säviä (26), Orijärvi (27), } \\
\text { AIJALA (28), Metsämonttu (29) }\end{array}$ & $\begin{array}{l}\text { Svionian black schists and carbonates, } \\
\text { associated with basic, intermediate and } \\
\text { salic volcanics }\end{array}$ & \\
\hline $\begin{array}{l}\mathrm{Cr}- \\
\mathrm{Fe}-\mathrm{Ti}-\mathrm{V}- \\
\mathrm{Ni}-\mathrm{Cu}-(\mathrm{Pt})-\end{array}$ & $\begin{array}{l}\text { KEMI (30) } \\
\text { MUSTAVAARA (31), OTANMÄKI (32), } \\
\text { Porttivaara (33), Suhanko (34) }\end{array}$ & $\left.\begin{array}{l}\text { Ultramafic rocks } \\
\text { Gabbros and anorthosites } \\
\text { Ultramafic rocks and norites }\end{array}\right\} \begin{array}{l}\text { Layered } \\
\text { intrusions }\end{array}$ & \\
\hline $\mathrm{Ni}-\mathrm{Cu}-$ & $\begin{array}{l}\text { HITURA (35), Makola (36), KOTALAH- } \\
\text { TI (37), Laukunkangas (38), Parikkala } \\
\text { (39), Telkkälä (40), Kylmäkoski (41), } \\
\text { Stormi (42), Sääksjärvi (43), Oravainen } \\
\text { (44) }\end{array}$ & $\begin{array}{l}\text { Ultramafic and basic pipe-like intrusions } \\
\text { around the batholith of Central Finland }\end{array}$ & \multirow{3}{*}{1.9} \\
\hline $\mathrm{Cu}-(\mathrm{Au})-\mathrm{As}-$ & $\begin{array}{l}\text { YLÖJÄRVI (45), HAVERI (46), Kopsa } \\
\text { (47) }\end{array}$ & $\begin{array}{l}\text { Upper Bothnian intermediate and basic } \\
\text { volcanics }\end{array}$ & \\
\hline Mo-Cu- & $\begin{array}{l}\text { Varparanta (48), Susineva (49), Kivi- } \\
\text { lompolo (50) }\end{array}$ & $\begin{array}{l}\text { Granites around the batholiths of Central } \\
\text { Finland and Central Lapland }\end{array}$ & \\
\hline $\begin{array}{l}\mathrm{Cu}-\mathrm{Zn}-\mathrm{Pb}- \\
\mathrm{Fe}-\end{array}$ & $\begin{array}{l}\text { KARSIKUMPU (51)? Korsnäs (54) } \\
\text { Silböle (52), Malmberg (53) }\end{array}$ & Skarn rocks with granites & 1.8 \\
\hline
\end{tabular}

character in North Ostrobothnia and Savo. In addition to these the Orijärvi (27), Aijala (28) and Metsämonttu (29) deposits in south-western Finland are, situated in the same environment.

Between the Jatulian metasediments and the basement complex there are, in places, layered intrusions and in connection with these ore deposits of $\mathrm{Cr}-, \mathrm{Fe}-\mathrm{Ti}-\mathrm{V}$ and $\mathrm{Ni}-\mathrm{Cu}-(\mathrm{Pt})$ are found (Fig. 2, 30-34). The best known of these intrusions lies on the southern border of the Peräpohja and Koillismaa schist areas. Near Kemi, in the western part of the intrusion zone there is a large deposit of chrome (30). The intrusion here is characterized by a large amount of ultramafic rocks. Near Mustavaara (31), in the middle of the zone there is a vanadium rich ilmenomagnetite deposit, which forms an extensive layer between gabbros and anorthosites. In places $(33-34)$ in the zone $\mathrm{Ni}-\mathrm{Cu}-(\mathrm{Pt})-$ mineralizations have also been found in the intrusions where spinel, as a cumulate, is lacking.

The same types of intrusions seem to have been 
formed in the southern border of the Kainuu schist area. This area, however, has been later metamorphosed and remobilized so thoroughly that only remnants of the intrusions are left. The Otanmäki Fe-Ti-V-ore deposits (32) belong to these remnants.

The other significant metallogenetic province is formed by areas around the batholith of Central Finland where the upper Bothnian schists with their volcanics and related intrusions are visible (Fig. 3, Table III, ore dep. 35-50). With respect to the metal composition the ores can be divided into $\mathrm{Cu}-(\mathrm{Au}-) \mathrm{As}-, \mathrm{Ni}-\mathrm{Cu}-$ and $\mathrm{Mo}-\mathrm{Cu}-$ types. The ore deposits of the first type have been found as breccias, veins, dikelets and disseminations within the upper Bothnian volcanics. The best known examples are Ylöjärvi (45) and $\mathrm{Ha}$ veri (46) in the Tampere schist area, but the same type of mineralizations have been found in many places in northern Ostrobothnia. As mentioned in the preceding chapter, at lower levels basic, ultrabasic, and salic intrusions of about the same age as the volcanics are also visible. Many of the basic and ultrabasic intrusions contain sulphide ores of $\mathrm{Ni}$ and $\mathrm{Cu}$. This type of ore has frequently been found in the so-called Raahe-Laatokka zone, in which zone the deposits Hitura (35) and Kotalahti (37) are being mined. On the opposite side of the batholith the best known deposits are Kylmäkoski (41), Stormi (42) and Sääksjärvi (43). Then, there exists a third type of mineralization, which is composed mainly of $\mathrm{Mo}$ and $\mathrm{Cu}$, which have been enriched in places by salic intrusions. The best known example is Susineva (49) in the northern part of the batholith of Central Finland. This type has also been found around the batholith of Central Lapland, where Kivilompolo (50) is the best known example.

As has already been mentioned, the Svecofennian schists are everywhere, and especially in southern Finland, cut by granites, 1.8 billion years old. On the basis of the lead model age most of the sulphide deposits in southern Finland have a connection with these granites (Kahma 1973). On the other hand many of the depos- its, for example Orijärvi (27), Aijala (28) and Metsämonttu (29) are similar in their metal content and environments to the sulphide deposits of northern Ostrobothnia and Savo, where the connection between the deposits and the old volcanics is evident. From that point of view it seems that during this granitic magmatism, at least, the lead was a moving component, which was enriched to old sulphide deposits but also to its own ores as for example in Korsnäs (54). In addition to lead copper and zinc were also enriched especially to the skarns. Furthermore magnetite can form a main component in the skarn deposits. The small iron deposits of Silböle (52) and Malmberg (53) are examples of skarn iron ores.

\section{The evolution of the Svecokarelian orogenic cycle and metallogenesis in Finland}

According to the age determinations, the Svecokarelian orogenic cycle began to develop something over 2.2 billion years ago. The initial orogenic belt involved two different geosynclinal zones, the Svecofennian and the Karelian. The way in which these geosynclines are related to each other can be deduced from the development of sedimenation, magmatism and the degree of deformation in the zones. In the light of these factors it seems that the Svecofennian geosyncline must have subsided to a much greater depth relative to the Karelian (Fig. 4). Thus the Svecofennian geosyncline in respect of the platetectonic pattern (e.g. Dewey \& Bird 1970) represents the consuming zone, where the crust pushed down relative to the foreland, where the Karelian geosyncline zone developed. At that time there were in the Karelian zone different depression basins, which became filled with sediments as their bottoms subsided (Fig. 5). The resulting sudden release of the stress field then led to block movements, during which the central parts of the depressions rose relative to the blocks further out into the foreland and in the culmination areas 


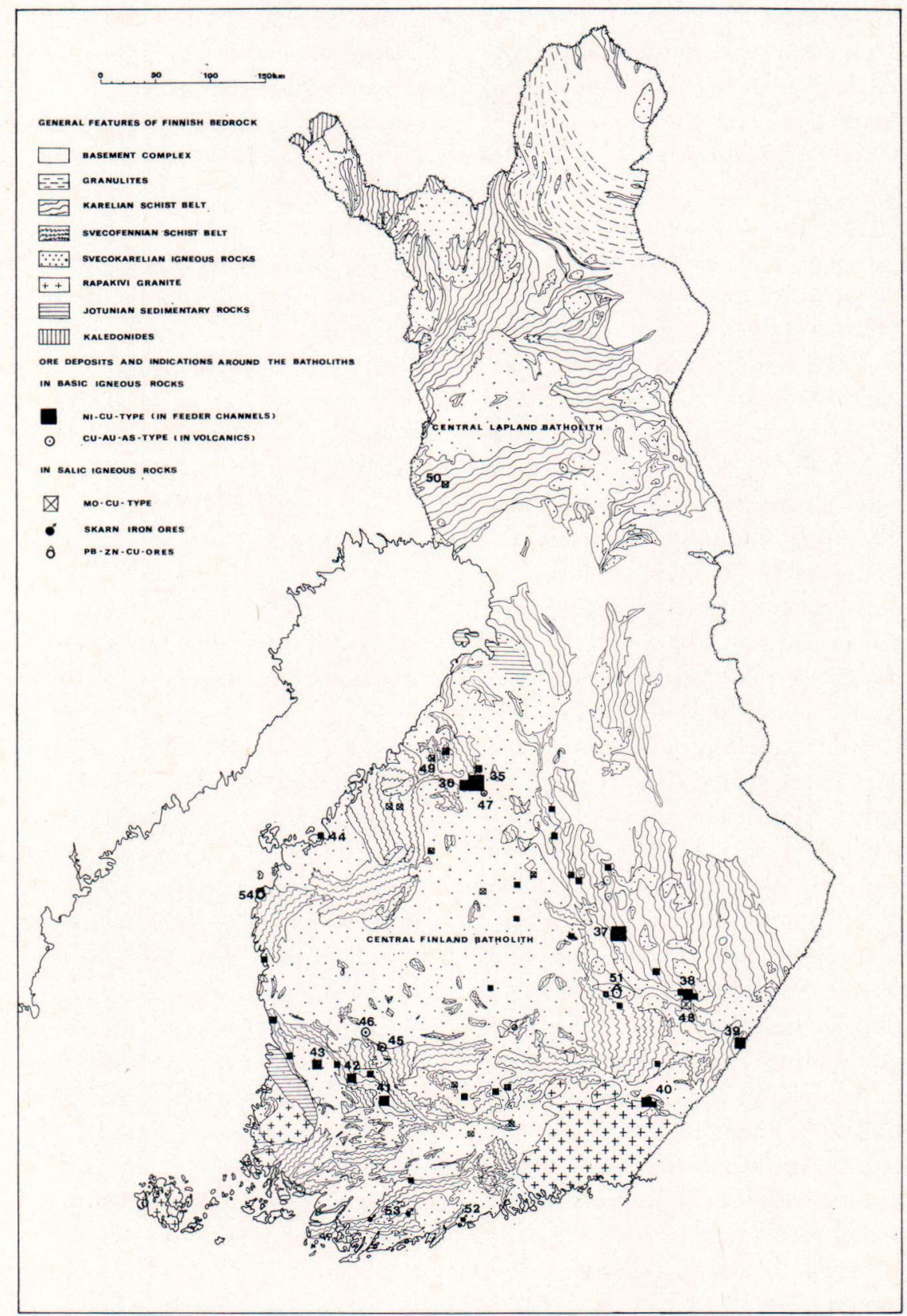

Fig. 3. Ore deposits connected with the upper Bothnian schists and related, and later igneous rocks. 


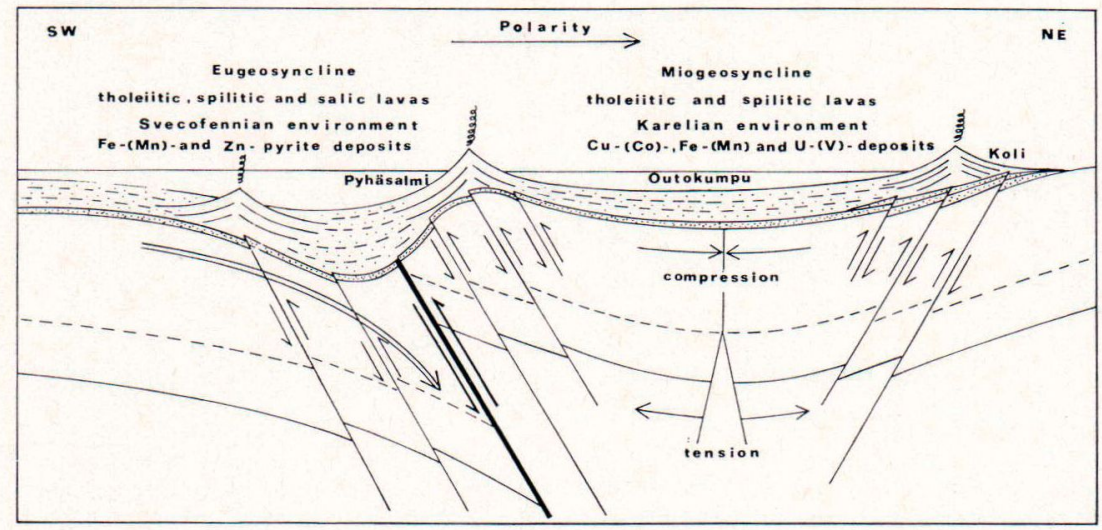

Fig. 4. Schematic section across the Svecofennian and Karelian geosynclines during the pre-flysch sedimentation and initial igneous activity about $2.1-2.2$ billion years ago (Piirainen, Hugg et al. 1974)

(Piirainen et al. 1974). This rhythm characterized sedimentation and volcanic activity in the Karelian zone during Jatulian time.

At the beginning of the orogeny movements were slow. Therefore the sediments had time to be thoroughly weathered and well sorted, of which the Jatulian and Svionian sediments give evidence. Circumstances were favourable for the deposition of sedimentary ores. In marine environments the iron was enriched and formed ironformations, while from the connate waters uranium and vanadium infiltrated through permeable horizons one after another and were adsorbed by the iron oxyhydrade previously precipitated there. The Jatulian and Svionian sediments, or the pre flysch as they can be called according to Aubouin (1968), form the most favourable environment for sedimentary ore deposits in the Svecokarelian belt in Finland.

From the point of view of metallogenesis the circumstances became increasingly more favourable both in the Karelian and Svecofennian geosynclines when the initial igneous activity began. The evolution of magmatism and metallogenesis was not, however, the same in each zone, because of the different geotectonic situations.

A high tension was produced in the upper mantle in the depression basins of the Karelian geosyncline zone, producing there conditions necessary for the generation of magmas (Fig. 4). The magmas thus generated rose along the tension field to the crust, from where they were further driven to the above-mentioned dislocation zones, along which they intruded into the borders of the basins (Fig. 5), where they are now visible as layered intrusions, sills, dikes and volcanics. The evolution of metallogenesis connected with this igneous activity was separated into two different branches. One branch was characterized by a low water content and conseguently a low fugacity of oxygen, the other branch by the opposite conditions.

The metallogenesis connected with the dry basic magmas developed in the culmination areas of the Karelian geosynclinal zone. Mustavaara in the Kainuu culmination between Central Lapland and Kainuu depressions, and its highly metamorphosed equivalent Otanmäki at the edge of the Kainuu depression and the North Karelian culmination are good examples of that metallogenetic environment. In dry conditions the cumulates were composed mainly of plagioclase. In the same conditions the sulphides of iron, nickel and copper formed an immiscible liquid separating from the magma to its own 


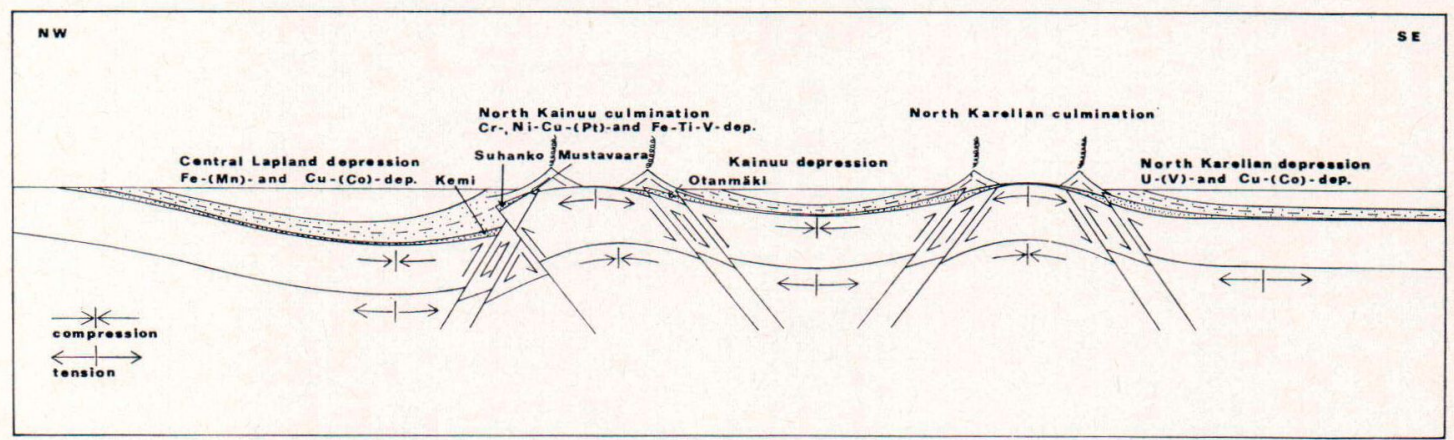

Fig. 5. Longitudinal profile of the Karelian geosyncline during the initial igneous activity about $2.1-2.2$ billion years ago (Piirainen, Hugg et al. 1974).

phase. In contrast to the sulphide metals, the oxides did not crystallize at an early stage and not until later were Fe-Ti-V-ores deposited.

Quite a different development of metallogenesis occurred in the inner parts of the depression basins, where the water content and accompanying fugacity of oxygen in the magma was considerably higher. In such conditions cumulates composed mainly of $\mathrm{Mg}$-Fe-silicates and spinel formed a chrome deposit as, for examples, the one near Kemi. In contrast to the spinel, the sulphides of $\mathrm{Ni}, \mathrm{Cu}, \mathrm{Fe}$ are lacking in these intrusions.

Some parts of the basic magmas were extremly contaminated by water and carbon dioxide. Thes parts crystallized to spilites, which are so common as hybabyssic intrusions and lavas within the Jatulian sediments. In the spilites the sulphides of $\mathrm{Cu}, \mathrm{Ni}, \mathrm{Co}$, and $\mathrm{Fe}$ were not formed an immiscible liquid but were enriched from magmas to the hydrothermal deposits and were exhalated to the geosyncline. The largest ore deposits of this type have been found in North Karelia and in Central Lapland. In addition to the $\mathrm{Cu}$-Co-ores in the last-mentioned area manganese deposits have also been found. In an environment of high oxygen fugacity more than iron, which need a lower potential to be oxidized, and therefore remaind in intrusions and lavas.
In the Karelian geosyncline the initial igneous activity produced only basic igneous rocks, which is in accordance with the geotectonics of this zone as stated above. The difference in the Svecofennian geosyncline, relative to the Karelian, is most obvious in the nature of the initial igneous activity, which in the Svecofennian zone produced not only basic but also large amounts of salic igneous rocks. Therefore it is clear that metallogenesis during the initial activity was different. Instead of copper and cobalt, zinc was here enriched to ore deposits. According to Krauskopf's (1964) thermodynamic statements, the enrichment of zinc favours the magmas rich in chlorine. Such magmas might have been developed in the Svecofennian geosyncline during the initial phase of the orogeny, when the oceanic plate with deep water sediments downthrust under the island arc. The deep water sediments, as we know, are rich in cholorine (Rösler \& Lange 1972 p. 37).

The Jatulian and Svionian sediments or the pre flysch and igneous rocks produced by the initial igneous activity $2.1-2.2$ billion years ago form the most important ore bearing horizon in the Svecokarelides in Finland. This horizon is covered in large areas by the Kalevian and Bothnian gray-wacke-slates representing the lower flysch sediments in the orogenic cycle. The extension of the lower flysch from the Sveco- 
TABLE 4.

Outlines of the Svecokarelian orogenic cycle and related metallogenesis in Finland.

\begin{tabular}{|c|c|c|c|c|c|}
\hline \multirow{2}{*}{$\begin{array}{c}\text { Orogenic } \\
\text { phase }\end{array}$} & \multirow{2}{*}{$\begin{array}{l}\text { Sedimenta- } \\
\text { tion phase }\end{array}$} & \multirow{2}{*}{$\begin{array}{l}\text { Igneous } \\
\text { phase }\end{array}$} & \multicolumn{2}{|c|}{ Geological processes and metallogenesis } & \multirow{2}{*}{$\begin{array}{l}\text { Age } \\
\text { inb.y. }\end{array}$} \\
\hline & & & Karelian zone & Svecofennian zone & \\
\hline 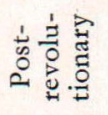 & Molasse & $\begin{array}{c}\text { Late- } \\
\text { orogenic }\end{array}$ & $\begin{array}{l}\text { Areal uprising, sedimentation char- } \\
\text { actirized by regression, salic ig- } \\
\text { neous activity (granites in places) }\end{array}$ & $\begin{array}{l}\text { Areal uprising, salic igneous activity } \\
\text { (granites), metallogenesis of } \mathrm{Fe}- \\
\text { and } \mathrm{Cu}-\mathrm{Zn}-\mathrm{Pb} \text {-skarn ores }\end{array}$ & 1.8 \\
\hline \multirow{2}{*}{ 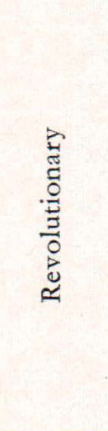 } & $\begin{array}{l}\text { Upper } \\
\text { flysch }\end{array}$ & $\begin{array}{l}\text { Sub- } \\
\text { sequent }\end{array}$ & $\begin{array}{l}\text { Uprising of the Central Lapland de- } \\
\text { pression to the batholith, related } \\
\text { sedimentation (upper Kalevian } \\
\text { group) and magmatism, metal- } \\
\text { logenesis of Mo-Cu-ores }\end{array}$ & $\begin{array}{l}\text { Uprising of the Central Finland de- } \\
\text { pression to the batholith, related } \\
\text { sedimentation (upper Bothnian } \\
\text { group) and magmatism (including } \\
\text { salic and basic branches), metallo- } \\
\text { genesis of Cu-(Au)-As-, Ni-Cu-, } \\
\text { and Mo-Cu-ores }\end{array}$ & \multirow[t]{2}{*}{1.9} \\
\hline & $\begin{array}{l}\text { Lower } \\
\text { flysch }\end{array}$ & $\begin{array}{c}\text { Syn- } \\
\text { orogenic }\end{array}$ & $\begin{array}{l}\text { Downwarping, downthrusting, fus- } \\
\text { ing to the Svecofennian geosyn- } \\
\text { cline, revolutionary sedimenta- } \\
\text { tion with turbidity currents (Ka- } \\
\text { levian group), local remolization } \\
\text { and remelting }\end{array}$ & $\begin{array}{l}\text { Downthrusting, revolutionary sedi- } \\
\text { mentation with turbidity currents } \\
\text { (lower Bathnian group), remobili- } \\
\text { zation and remelting }\end{array}$ & \\
\hline 胥 & Preflysch & Initial & $\begin{array}{l}\text { Downwarping, evolutionary sedi- } \\
\text { mentation (Jatulian group), basic } \\
\text { igneous activity, metallogenesis } \\
\text { of } \mathrm{U}-(\mathrm{V})-, \mathrm{Fe}-(\mathrm{Mn})-, \mathrm{Cu}-(\mathrm{Co})- \\
\text { and } \mathrm{Fe}-\mathrm{ores} ; \text { layered intrusions, } \\
\text { metallogenesis of } \mathrm{Cr}-, \mathrm{Fe}-\mathrm{Ti}-\mathrm{V} \\
\text { and } \mathrm{Ni}-\mathrm{Cu}-(\mathrm{Pt}) \text {-ores }\end{array}$ & $\begin{array}{l}\text { The Benioff zone with the island arc } \\
\text { moving from south-west to north } \\
\text {-east (Svionian sedimentary group } \\
\text { with basic and salic volcanics), } \\
\text { metallogenesis of } \mathrm{Fe} \text {-(Mn)- and } \\
\mathrm{Zn}-\mathrm{Cu} \text {-pyrite ores }\end{array}$ & 2.1 \\
\hline
\end{tabular}

fennian zone to the Karelian zone provides evidence for the point of view that both geosynclines have been fused into one after the initial igneous activity. The Central Lapland depression basin was, however, developed as a part of one geosyncline zone, which has the same features as the Svecofennian. Simultaneously the lower flysch in the deepest depressions was mobilized and recrystallized to granites, granodiorites, throndjemites, diorites, and different gneisses, corresponding to Stille's (1938) synorogenic plutonic rocks.

The lower flysch and synorogenic plutonism were not favorable for the deposition of ores. In this respect the circumstances changed completely when the deepest subsided depressions began to rise up or the orogenesis passed from the lower flysch to the upper flysch in the sedi- mentation and from synorogenic plutonism to the subsequent volcanism in the igneous activity. This volcanism was vigorous around the rising batholith of Central Finland and produced not only salic but also basic volcanics. The related basic and salic intrusions which border the batholith in the lower level are also visible (Fig. 1 and 3). The Subsequent volcanism therefore has a greater significance in the Svecofennian orogeny than in its original meaning in Stille's statements. This magmatic phase had a metallogenetic importance. The basic and ultrabasic intrusions contain $\mathrm{Ni}-\mathrm{Cu}$-ore deposits whereas the ores in salic intrusions are chracterized by $\mathrm{Mo}$ and $\mathrm{Cu}$. In the related volcanics $\mathrm{Cu}, \mathrm{Au}$ and $\mathrm{As}$ are then enriched to ore deposits.

The orogenic movements still continued after the upper flysch sedimentation and subsequent 
magmatism and the formations of this phase were metamorphized in the amphibolite facies. Then, during the areal uprising, that is about 1.8 billion years ago, microcline granites were intruded. These granites reacted with the carbonate rocks produceing skarns, and related ore deposits of
$\mathrm{Fe}$ and/or $\mathrm{Cu}, \mathrm{Zn}$ and $\mathrm{Pb}$. This late orogenic magmatism formed the last metallogenetic epoch within the Svecokarelian orogenic cycle. After the intrusion of the microcline granites the orogenic belt was cratonized to the continent.

\section{REFERENCES}

Aubouin, J. (1965) Geosynclines, Developments in geotectonics 1. Elsevier, Amsterdam.

Dewey, J. F. and BrRD, J. M. (1970) Mountain belts and the new global tectonics. J. Geophys» Res. 75.

Eskola, P. (1914) On the petrology of the Orijärvi region in southwestern Finland. Bull. Comm. Géol. Finlande 40 .

EsкоLA, P. (1927) Petrographische Gharacteristik der kristallinen Gesteine von Finnland. Fortschr. Miner. 11.

GAÁL, G. (1972) Tectonic control of some Ni-Codeposits in Finland. Int. Geol. Congr. 24th session, Montreal. Sect. 4.

Geological Survey of Finland. Annual report on the activities for the years 1965-1973.

Härme, M. (1954) Structure and stratigraphy of the Mustio area, southern Finland. Bull. Comm. Géol. Finlande 166.

Kанма, A. (1973) The main metallogenic features of Finland. Bull. Geol. Surv. Finland. 265.

Kouvo, O. (1958) Radioactive age of some Finnish Precambrian minerals. Bull. Comm. Géol. Finlande 182.

Kouvo, O., Hart, S. R., Aldrich, L. T., Davis, G. L., Tilton, G. R., BaAdsgaArd, H. and Steiger, B.H. (1963) Isotope mineral ages on Finnish Precambrian. Geochronology and Isotope Geology. Garnegie Inst. Washington, Year Book 62.

Kouvo, O. and Tilton, G. R. (1966) Mineral ages from the Finnish Precambrian. J. Geol. 74.

Krauskopf, K. (1964) The possible role of volatile metal compounds in ore genesis. Econ. Geol. 59.

Matisto, A. (1968) Die Meta-Arkose von Mauri bei Tampere. Bull. Comm. Géol. Finlande 235.

Metzger, A. Th. (1945) Zur tektonischen Stil von Palingengranit und Marmor in den Svecofenniden in Finland. C. R. Soc. Géol. Finlande 20. Bull. Comm. Géol. Finlande 140.
Metzger, A. Th. (1959) Svecofenniden und Kareliden; eine kritische Studie. Medd. Åbo Akad. Geol. Miner. Inst. 41.

Mrkкola, T. (1953) Peruskalliogeologian näköaloja. Geologi 5.

MÄKELÄ, K. (1968) Sirkka-muodostumasta ja stratigrafian yleispiirteistä Keski Lapin liuskealueella. Lic. Phil. thesis. Manuscript at the Dep. of Geol., Univ. of Oulu.

MäKınEN, E. (1914) Ytterligare en kontakten vid Naarajärvi i Lavia. GFF 36. 3.

PaAk kola, J. (1971) The volcanic camplex and associated manganiferous iron formation of the Porkonen-Pahtovaara area in Finnish Lapland. Bull. Comm. Géol. Finlande 247.

Pirrainen, T. (1968) Die Petrologie und die Uranlagerstätten des Koli-Kaltimo Gebiets im finnischen Nordkarelien. Bull. Comm. Géol. Finlande 237.

Pirrainen, T. (1969) Initialer Magmatismus und seine Erzbildung in der Beleuchtung des Koli-Kaltimo Gebiets. Bull. Géol. Soc. Finland 41.

Pitrainen, T., Hugg, R., Isohanni, M. and Juopperi, A. (1974) On the geotectonics and ore forming precesses in the basic intrusive belts of Kemi-Suhanko, and Syöte-Näränkävaara, northern Finland. Bull. Geol. Soc. Finland 46.

Pitrainen, T., Honkamo, M., and Rossi, S. (1974) A preliminary report of the Koli area. Bull. Geol. Soc. Finland 46.

Pirspanen, R. (1971) On the spilitic rocks of the Karelitic belt in western Kuusamo, northeastern Finland. Acta Univ. Ouluensis, Ser. A, Geologica No. 2.

Rösler, H. J. and LANGe, H. (1972) Geochemical tables. Elsier, Amstedam.

SАкко, M. (1971) Varhais-karjalaisten metadiabaasien radiometrisiä zirkoni-ikiä. Summary: Radiometric zirkon agea on the Early-Karelian metadiabases. Geology 23. 
SAKSElA, M. (1932) Tektonische und stratigraphische Studien im mittleren Ostrobothien, mit einigen Vergleichspunkten aus anderen Gebieten. C.R. Soc. Géol. Finlande 5 .

Sederholm, J. J. (1891) Studien über archäische Eruptivgesteine aus dem südwestlichen Finnland. Miner. Petr. Mitt. 12.

Sederholm, J. J. (1897) Über eine archäische Sedimentformation im südwestlichen Finnland und ihre Bedeutung für die Erklärung der Entstehung des Grundgebirges. Bull. Comm. Géol. Finlande 6 .

Sederholm, J. J. (1932) On the geology of Fennoscandia with special reference to the pre-Cambrian. Explanatory notes to accompany a general geological map of Fennoscandia. Bull. Comm. Géol. Finlande 98.

SeITSAARI, J.(1951) The schist belt northeast of Tampere in Finland. Bull. Comm. Géol. Finlande 153.

SilvennoInen, A. (1972) On the stratigraphic and structural geology of the Rukatunturi area, northeastern Finland. Geol. Surv. Finl. Bull. 257.

Simonen, A. (1953) Stratigraphy and sedimentation of the Svecofennidic, early Archean supracrustal rocks in southwestern Finland. Bull Comm. Géol. Finlande 160.
Simonen, A. (1960 a) Pre-Quaternary rocks in Finland. Bull. Comm. Géol. Finlane 191.

Simonen, A. (1960 b) Pre-Cambrian stratigraphy of Finland. XXI Int. Geol. Congress, Norden 1960 , Section 9.

Srmonen, A. (1971) Das finnische Grundgebirge. Geol. Rundschau 60.

Strlle, H. (1938) Die Grossfelder der Erdkruste und ihr Magmatismus (kurzes Vortragsprotokoll). Sitzungsber. d. Preuss. Akad. d. Wiss. Phys. -math. Kl. $51-52$.

Tuominen, H. (1957) The structure of an Archean area: Orijärvi, Finland. Bull. Comm. Géol. Finlande 177.

Wegman, C. E. (1928) Üder die Tektonik der jüngeren Faltung in Ostfinnland. Fennia 50 (16).

VäYRYNEN, H. (1928) Geologische und petrographische Untersuchungen im Kainuu-gebiete. Bull. Comm. Géol. Finlande 78.

VÄYRYNEN, H. (1933) Über die Stratigraphie der karelischen Formationen. C. R. Soc. Géol. Finland 6. Bull. Comm. Géol. Finlande 101.

VÄYRYNEN, H. (1954) Suomen kallioperä, Otava Helsinki.

Manuscript received, February 27, 1975. 